\title{
Factors Affecting Tourism Industry of Nepal
}

\author{
Dr. Prakash Shrestha \\ Lecturer, Nepal Commerce Campus, Tribhuvan University, Nepal \\ Dr. Dilip Parajuli* \\ Associate Professor, Bhaktapur Multiple Campus, Tribhuvan University, Nepal
}

\begin{abstract}
The purpose of this study is to find the factors that are affecting the Nepalese tourism industry and SWOT analysis. The primary data was used to determine the factors influencing the Nepalese tourism industry in order to explore them. The questionnaire survey was conducted from March to May 2019. Data was collected from managers of sample hotels \& travel agencies and tourists visiting various places of Nepal. An exploratory research design was used. Simple descriptive statistical tools such as frequencies, mean, standard deviation, and rank were used as statistical tools. The results show that the heritage tourism, religious tourism, cultural tourism, adventure or ecotourism, wildlife tourism, and sports tourism are the positive factors whereas lack of infrastructure, ineffective promotional policies, inadequate tourist's services and facilities, inadequate knowledge and training of personnel in the tourism sector, inadequate infrastructure facilities, and lack of incentives in the tourist sector are the negative factors. The important aspect or value of this research is that it has brought into consideration almost all the important factors that are affecting the Nepalese tourism industry according to the view of managers and tourists. Keywords: Factors, Negative factors, Positive factors, SWOT, Tourism industry, Tourists
\end{abstract}

DOI: $10.7176 / \mathrm{JTHS} / 51-04$

Publication date:October $31^{\text {st }} 2020$

\section{Introduction}

Nowadays, people from one country are moving to other countries. They are the means of the tourism industry. The tourism industry includes business units engaged in tourist lodging, motel, hotel, restaurant, resort, travel agency, skiing, gliding, water rafting, cable car complex, pony-trekking, trekking, hot air ballooning, parasailing, golf-course, polo, horse-riding, and the like. Tourism is a major industry in Nepal (Pant, 2014). In 2018, Nepal's travel and tourism contribution to GDP (percentage of GDP) was 7.9 percent (MoF, 2018/19).

Tourism has found its potential as an engine of development for a country in this global age. It is seen as a vital source of a country's reduction in the current account deficit through foreign exchange earnings and growth. As a foundation for strengthening political, cultural, and economic links between nations, it has gained currency in international relations. Tourism guarantees the foreign exchange inflow that can be used in the country to import capital goods and thus the creation of capital. In the economic context, tourism, which is sometimes referred to as an industry, does not employ input factors or operate the variables typically employed in the production process. It is labor-intensive and is considered to be part of the economy's non-traded market as it offers services to the domestic and international sectors of the economy. This forms the intangible part of the account of the balance of payments (Ghartey, 2010). Nowadays, the tourism industry contributes to several nations' sources of foreign income. It also plays a significant role in many countries' economic, cultural, and social growth. It could lead to increased production, a higher standard of living, increased public health, and high-level jobs if properly managed (Assadzadeh \& Nasab, 2012).

Tourism consists of both the consumption portion of travelers visiting foreign countries for leisure reasons and the development portion of travelers visiting countries for business reasons. It is usually normal for the same individuals or tourists who visit a country for business to end up spending some time there for recreation. As a consequence, tourism can not be explicitly considered to be a commodity purely for consumption or production. In addition, tourism is nice in which the end-user is transported to the products and services, unlike other products that are transported to the end-user (O'Hagan \& Harrison, 1984). It is also regarded as an import by Gray (1966), although it is known to be an export in other studies (Carey, 1991, cited in Ghartey, 2010). Today, for many nations, this industry is a great income resource and most governments strongly support the tourism industry. In different studies, it has been found that tourism and economic growth have a deep relation. By reducing the current account deficit, it increases the balance of payments accounts of the nation (Malik et al., 2010). Most of the least developed countries (LDCs), such as Nepal, have poor foreign market competition in their exports. Owing to meager exports and strong inelastic imports, their current account poses a persistent deficit. This can, however, be remedied if these countries placed greater emphasis on the service sector, especially tourism.

Brau et al. (2003) suggest that their economic development can be accelerated by small countries that specialize in tourism. This ensures that the country will take advantage of the tourism sector as a source of stable foreign exchange earnings and fund its immense national debt in order to fulfill its balance of payment obligations. 
By being exposed to high competition in the world market, the tourism sector can also contribute to the country's economic growth by improving economic productivity and promoting economies of scale of production among the country's firms. Foreign exchange income from the tourism industry can also help the country finance the import of capital and raw materials needed for the country's development and economic growth (Kim et al., 2006; Brau, 2003; Balaguer \& Cantavella-Jorda, 2002; Krugman \& Helpman, 1985; Bhagwati \& Srinivasan, 1979, cited in Ghartey, 2010). These discussions justify the significance of a study on the tourism industry.

\section{Objective of the Study}

The main objective of this study is to identify the positive and negative factors affecting the tourism industry in Nepal and to perform a SWOT analysis to identify the strengths, weaknesses, opportunities, and threats to the tourism industry in Nepal.

\section{Rationale of the Study}

Nepal seems to be a perfect place for tourists to visit, but still, the arrival of tourists is not sufficient as anticipated. This study, therefore, derives its importance from its possible contribution by analyzing in both a positive and negative way the factors influencing the tourism industry. The study also uncovers the tourism industry's latent potential. The SWOT analysis through which the parties concerned can recognize the strengths, weaknesses, opportunities, and threats of the tourism industry in Nepal is another impetus behind this study.

\section{Tourism Potentiality Assessment}

Nepal is a nation of unimaginable extremes and fascinating beauty. It is also the land of the brave Gurkhas and the birthplace (the apostle of peace) of Lord Buddha. Here are the world's highest mountains covered in snow, like Mt. Everest $(8,848 \mathrm{~m}$.) panoramically looming over green hills and terraced valleys. Farmlands with carefully carved stairways, on hill ridges, on thundering rivulets and rivers, or in forests full of wildlife or birds and beautiful flowers, magic is everywhere. Here's something for anyone in search of a perfect Shangri-La, be it a tourist, a trekker, or wanderlust (Upadhay, 2006). The impact of visiting the Durbar Squares of Kathmandu and Patan or walking through the street of Bhadgaon (Bhaktapur) for the first time is very strong. Nepal is also blessed with rich biodiversity which includes vegetation ranging from alpine to temperate and varied wildlife such as the Bengal Tigers, one-horned rhinoceros, and rare chance to view them from the back of an elephant or pursuing endemic forms of tourism (CEDA, 1997).

The contribution of earnings through tourism in the Nepalese economy can be categorized as moderate (Bhattarai, 2008). Nepal offers a comparative advantage in very few specific sectors, one of which is tourism. Visitors can look for something different here where they take a break from their day-to-day ultra-modern urban lives. Nepal's greatest advantage lies in its diverse ecological zones, the Terai, hills, and mountains. It has four major river systems namely, Koshi, Gandaki, Karnali, and Mahakali that have been perennial sources of civilization, nation, state, and economic development from time immemorial (Dahal, 1999 cited in Bhattarai, 2008). Healthy and varied natural and socio-cultural environment are the basic resources for tourism development. The areas or country with outstanding natural beauty (national parks, hills, and mountains, fell and dale, cliffs, wildlife, climate, etc.) and living socio-cultural heritage (historical remains, sacred shape, delightful villages, and lifeworld, etc.) are the most preferred and successful environment for the modern tourism. Poudel (1996), Kaur (1995) have presented a basis for analyzing natural and socio-cultural resources of tourism (Table 1). 
Table 1: Tourism Potentiality Assessment Criteria

\begin{tabular}{|c|c|c|}
\hline Group Heading & Criteria & Factors to be Considered \\
\hline \multirow{8}{*}{$\begin{array}{l}\text { Natural } \\
\text { Factors }\end{array}$} & \multirow[t]{4}{*}{ 1. Scenic Beauty } & $\begin{array}{l}\text { - Mountain Scenery: Snow peaks \& outstanding } \\
\text { mountains, glaciers, panoramic view, green slopes }\end{array}$ \\
\hline & & - Varied Geologic features \& formation \\
\hline & & $\begin{array}{l}\text { - Valley Aspects: gorges, glaciated valleys, scenic \& } \\
\text { wild rivers }\end{array}$ \\
\hline & & $\begin{array}{l}\text { - Water Bodies: Lakes, waterfall, natural spring (hot } \\
\text { \& cold), rivers, streams \& confluences }\end{array}$ \\
\hline & \multirow[t]{3}{*}{ 2. Flora \& Fauna } & $\begin{array}{l}\text { Forests: local forest type, primitive forest, largest } \\
\text { \& oldest trees, unique flora }\end{array}$ \\
\hline & & $\begin{array}{l}\text { - Meadows: the Himalayan meadows and flower } \\
\text { valleys }\end{array}$ \\
\hline & & - Fauna: popular type \& rare species, \\
\hline & 3. Climate & $\begin{array}{l}\text { - Temperature: length of sunshine, precipitation, } \\
\text { atmosphere quality \& comfort }\end{array}$ \\
\hline \multirow{6}{*}{$\begin{array}{c}\text { Social } \\
\text { Factors }\end{array}$} & \multirow[t]{2}{*}{ 4. Religious Significance } & $\begin{array}{l}\text { Pilgrim Centers: international, national, regional \& } \\
\text { local }\end{array}$ \\
\hline & & - Rituals \& observances \\
\hline & \multirow[t]{2}{*}{ 5. Fairs \& Festivals } & $\begin{array}{l}\text { - Fairs: religious, cultural, commercial \& the } \\
\text { commons }\end{array}$ \\
\hline & & - Festivals: local \& national \\
\hline & 6. Distinctive Local features & $\begin{array}{l}\text { - Ethnic and cultural diversity, tribal groups, life } \\
\text { style, dress, jewelry \& folk tradition }\end{array}$ \\
\hline & $\begin{array}{l}\text { 7. Artistic and Architectural } \\
\text { features }\end{array}$ & $\begin{array}{l}\text { - Local architecture, temples \& sculpture \& } \\
\text { paintings }\end{array}$ \\
\hline \multirow{2}{*}{$\begin{array}{l}\text { Historical } \\
\text { Factors }\end{array}$} & \multirow{2}{*}{$\begin{array}{l}\text { 8. Historical/Archaeological } \\
\text { Sites \& Events }\end{array}$} & - Places of historical importance \\
\hline & & - Ancient sites, events \& legends \\
\hline \multirow{3}{*}{$\begin{array}{l}\text { Recreation } \\
\text { \& Shopping } \\
\text { Facilities }\end{array}$} & 9. Sports Facilities & $\begin{array}{l}\text { Mountaineering, adventure activities, rock } \\
\text { climbing, skiing, rafting, hunting, jungle safari, } \\
\text { photography, gliding, etc. }\end{array}$ \\
\hline & 10. Facilities for Health \& Rest & $\begin{array}{l}\text { - National parks, sanctuaries, botanical gardens, } \\
\text { picnic grounds }\end{array}$ \\
\hline & 11. Shopping Opportunities & - Groceries \& necessities \\
\hline $\begin{array}{l}\text { Infrastructure, } \\
\text { Food \& Shelter }\end{array}$ & $\begin{array}{l}\text { 12.Infrastructures of Minimum } \\
\text { Quality }\end{array}$ & $\begin{array}{l}\text { - Highway, roads, electricity, safety, facilities, hotels } \\
\text { of diff. quality, restaurants, etc. }\end{array}$ \\
\hline
\end{tabular}

Nepal's primary attraction is its unique geographic situation. It straddles not only the Himalayas- the highest mountain range in the world- but also the great socio-cultural traditions of India to the south and of Tibet to the north and provides tourists with unsurpassed opportunities for natural and socio-cultural esthetics. Thus, discussing the tourism potentials of Nepal everyone has to consider both natural and socio-cultural attractions setting or adopting scientific criteria. Broadly speaking such criteria can be used as a basis for analyzing the tourism potentials of a developing country like Nepal.

\section{Research Methodology}

An exploratory research design is being used in this study. The primary data was used to determine the factors influencing the Nepalese tourism industry in order to explore them. The questionnaire survey was conducted from March to May 2019. Data was collected from managers of sample hotels \& travel agencies and tourists visiting various places of Nepal. The characteristics of these respondents are presented in Table (2) and Table (3) respectively.

Table 2: Characteristics of Selected Nepalese Managers $(\mathbf{N}=\mathbf{2 0})$

\begin{tabular}{|l|l|c|c|c|}
\hline S.N. & \multicolumn{1}{|c|}{ Name of Organizations } & Numbers & $\begin{array}{c}\text { Average } \\
\text { Age (Years) }\end{array}$ & $\begin{array}{c}\text { Average Work } \\
\text { Experience in (Years) }\end{array}$ \\
\hline 1. & Managers of Selected Hotels & 5 & 42.80 & 12.40 \\
\hline 2. & Managers of Selected Travel Agencies & 15 & 37.40 & 9.8 \\
\hline & Total & 20 & 38.75 & 10.45 \\
\hline
\end{tabular}


Table 3: Characteristics of Tourists $(\mathrm{N}=150)$

\begin{tabular}{|l|l|c|c|c|}
\hline S.N. & Name of Country & Tourists (Percent) & $\begin{array}{c}\text { Average Age } \\
\text { (Years) }\end{array}$ & $\begin{array}{c}\text { Average Length of Stay } \\
\text { (Days) }\end{array}$ \\
\hline 1. & America & 16.67 & 31.60 & 10.20 \\
\hline 2. & China & 16 & 44.25 & 11.50 \\
\hline 3. & France & 10 & 28.20 & 11.60 \\
\hline 4. & Germany & 11.33 & 27.60 & 11.60 \\
\hline 5. & India & 18.67 & 42.0 & 12.00 \\
\hline 6. & Switzerland & 10 & 26.5 & 13.25 \\
\hline 7. & UK & 17.33 & 29.0 & 12.80 \\
\hline
\end{tabular}

Questionnaires objects were measured (strongly agreed to strongly disagree) using a Likert scale ranging from 5 to 1 . More or less the approach used by Fakhar (2008) was adapted by this research. As statistical instruments, basic descriptive statistical methods such as frequencies, mean, standard deviation, and rank were used. The reliability coefficients of internal consistency for all the scales were satisfactory. All scales had a Cronbach Alpha coefficient greater than 0.75 .

\section{Empirical Findings and Analysis}

This section presents positive and negative factors affecting the Nepalese tourism industry and the results of the SWOT analysis of this industry.

\subsection{Positive and Negative Factors}

Some of the evidenced-based positive and negative factors affecting Nepal's tourism industry are presented in Table 4 and Table 5.

Table 4: Positive factors affecting the tourism industry of Nepal $(\mathrm{N}=170)$

\begin{tabular}{|c|c|c|c|c|}
\hline Factors & Mean & S.D. & Reliability (Cronbach Alpha) & Rank \\
\hline $\begin{array}{l}\text { Presence of tourist attractions } \\
\text { Mountains } \\
\text { Valleys } \\
\text { Lakes } \\
\text { Historical places }\end{array}$ & 4.6 & 0.51 & \multirow{9}{*}{0.93} & 1 \\
\hline Rich culture & 4.5 & 0.71 & & 2 \\
\hline Rich food & 4.02 & 0.62 & & 4 \\
\hline Festivals & 4.4 & 0.73 & & 3 \\
\hline Hotels & 4.01 & 0.68 & & 5 \\
\hline Restaurants & 3.96 & 0.84 & & 6 \\
\hline Handicrafts & 3.8 & 0.72 & & 7 \\
\hline Museums & 3.7 & 0.64 & & 8 \\
\hline Business environment & 3.26 & 0.59 & & 9 \\
\hline
\end{tabular}

Table 5: Negative factors affecting the tourism industry of Nepal $(N=170)$

\begin{tabular}{|c|c|c|c|c|}
\hline Factors & Mean & S.D. & $\begin{array}{c}\text { Reliability } \\
\text { (Cronbach } \\
\text { Alpha) } \\
\end{array}$ & Rank \\
\hline Unfair political practices & 4.6 & 0.57 & \multirow{12}{*}{0.91} & 1 \\
\hline $\begin{array}{l}\text { The negative image of Nepal is portrayed by media to the } \\
\text { outside world. }\end{array}$ & 4.3 & 0.68 & & 7 \\
\hline Lack of infrastructure & 4.5 & 0.72 & & 2 \\
\hline Ineffective promotional policies & 4.42 & 0.81 & & 4 \\
\hline Inadequate tourist's services and facilities & 4.2 & 0.76 & & 10 \\
\hline Lack of initiative by concerned government departments & 4.32 & 0.81 & & 6 \\
\hline $\begin{array}{l}\text { Inadequate knowledge and training of personnel in tourism } \\
\text { sector }\end{array}$ & 4.15 & 0.74 & & 12 \\
\hline Lack of incentives in the tourist sector & 4.35 & 0.87 & & 5 \\
\hline Low allocation of annual tourist budget & 4.19 & 0.79 & & 11 \\
\hline Lack of development and facilities in the mountain regions & 4.47 & 0.83 & & 3 \\
\hline Lack of understanding to the tourist needs & 4.24 & 0.61 & & 9 \\
\hline High inflation rate & 4.26 & 0.67 & & 8 \\
\hline
\end{tabular}




\subsection{SWOT Analysis of the Nepalese Tourism Industry}

The study of SWOT stands for strengths, weaknesses, opportunities, and threats. The below-mentioned SWOT review reflects the views and experiences of managers of hotels \& travel agencies of Nepal.

Table 6: SWOT Analysis of the Nepalese Tourism Industry

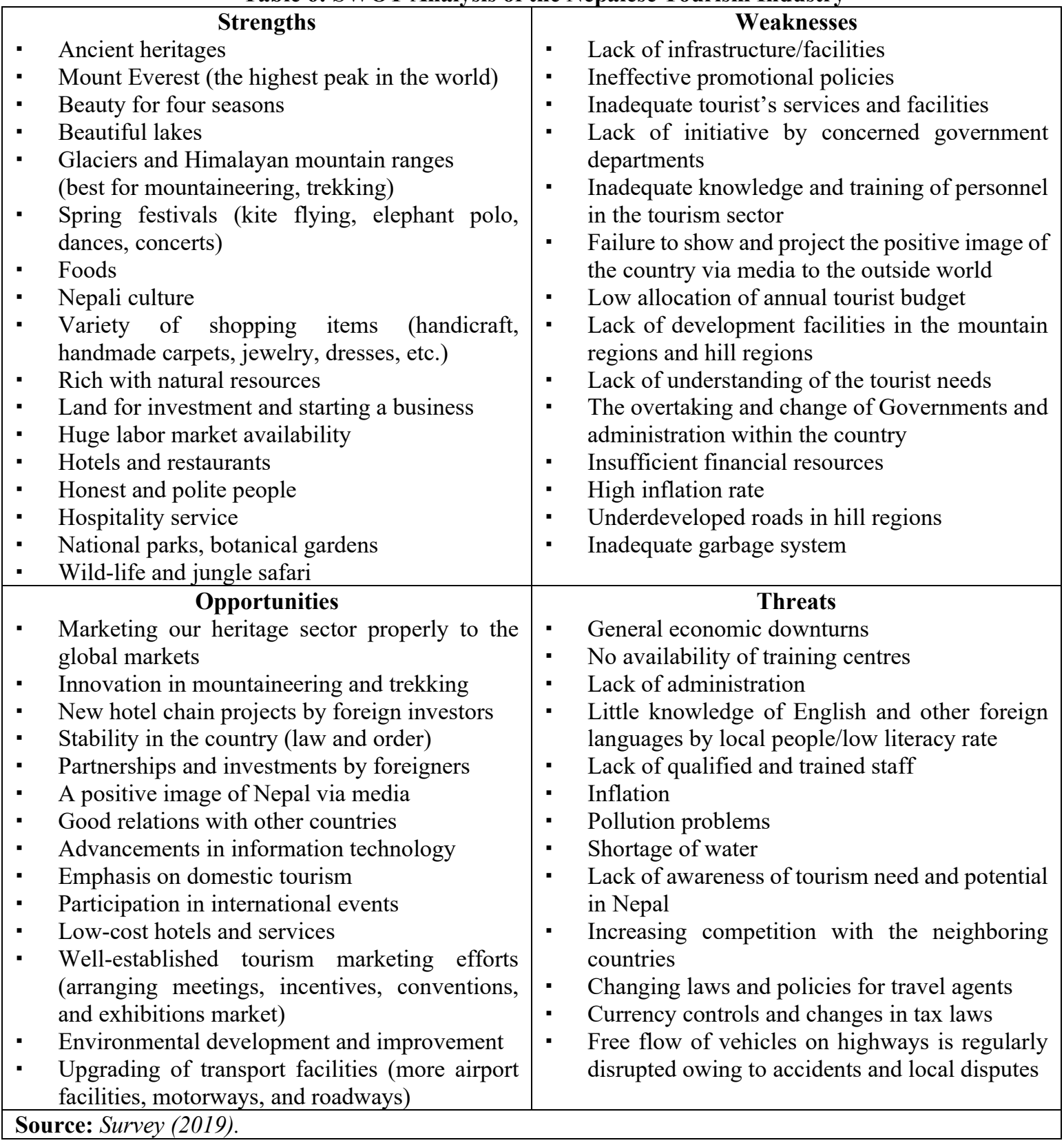

\section{Discussion and Conclusion}

Traveling has become an excellent remedy for the stress and anxiety demanded by our modern-day life schedules. People prefer to change when they get holidays so that they can relax their minds and spend some quality memorable time. Therefore, tourism has become a popular global leisure activity and is the most dynamic and current growing industry in the world. Tourism activity and tourists are important because it is the most effective mean of exploring other countries, its people, and their culture whereas the tourists help in building the bridges between nations through love, mutual understanding, and knowledge, thus bringing different cultures together (Fakhar, 2008). The tourism industry is becoming one of the important service industries in Nepal. Its contribution to the national income is countable.

Based on the study the major positive factors affecting the Nepalese tourism industry are the presence of tourist attractions (such as mountains, valleys, lakes, and historical places), rich culture, rich food, festivals, hotels, restaurants, handicrafts, museums, and business environment. On the other hand, the biggest negative factor affecting the tourism industry according to the respondents is unfair political practices. The lacking facilities 
include the unavailability of high-quality hotels and restaurants. Most of the hotels don't reach and meet the high expectations of foreign tourists. The lack of internet and cellular service in most parts is a big problem faced by tourists. Transport facilities are not so much systematic. Land sliding in mountain areas is common and the roads are not of the best quality and ultimately they are not safe.

Based on the view of respondents, factors affecting tourism negatively include a high inflation rate. Tourism is becoming a leisure activity for the elite class only. The government is spending little on the tourism industry. Based on SWOT analysis and the opinion of interviewed respondents and filled the questionnaire, the Nepalese tourism industry has many strengths and potentials. It possesses nature, the highest mountains, holy places and sites, amazing culture, tasty foods, festivals throughout the seasons, handicrafts, and rich natural resources. Nepal has hotels and restaurants ranging in quality and price from lowest to highest quality and price. Hotel Pokhara Grande, Hotel Annapurna, Hotel Mall, Shangrila Hotel, Soaltee Crown Plaza, The Everest Hotel, The Hotel Yak and Yati, The Raddison Hotel are some of the names of hotels in Nepal. Likewise, tourists can enjoy local to international high quality and price food chains like KFC. Shopping in Nepal is quite cheap for foreigners, as they love to shop for handicrafts, handmade carpets, decoration items, Pashmina shawls, embroidered shirts/shoes, gems, and jewelry, etc.

Inner peace and security of the country are the most important factors for promoting the tourism industry in Nepal. In presenting its positive picture as well, the media should play a positive role. For the growth of this sector, the local community should also play their roles, such as keeping the country clean, providing visitors with guesthouses with the availability of essential facilities such as the internet and healthy foods. Every Nepalese citizen should play a positive role in promoting tourism by being hospitable and accommodating in every respect.

\section{Limitation and Direction for Further Research}

Although the current study has addressed some of the major factors affecting the tourism industry in Nepal, this study has some limitations. The sample is small as the only focus is on managers of selected hotels and travel agencies and tourists visiting multiple tourist locations. Therefore, considering different locations, it is possible to do further analysis. Another limitation is the approach used for this study is that people's interviews are heavily affected by their moods and comfort levels.

\section{References}

Assadzadeh, A., \& Nasab, M. H. N. (March 2012). Investigating the relationship between tourism industry and GDP in the Islamic Republic of Iran. International Review of Business Research Papers, 8(2), 85-95.

Balaguer, J., \& Cantavella-Jorda, M. (2002). Tourism as a long-run economic growth factor: the Spanish case. Applied Economics, 34(7), 877-884.

Bhagwati, J., \& Srinivasan, T. (1979). Trade policy and development. In R. Dornbusch and J. Frenkel (eds.) International Economic Policy: Theory and Evidence. Baltimore, MD: Johns Hopkins University Press.

Bhattarai, S. (2008). The role of tourism in the economic development of Nepal. The Central Department of Economics, Tribhuvan University, Kirtipur, Kathmandu.

Brau, R., Lanza, A., \& Pigliaru, F. (2003). How fast are the tourism countries growing? the cross-country evidence, CRENoS Centre Ricerche Economiche Nord Sud Working Paper, No. 03/09, 1-34.

Carey, K. (1991). Estimation of the Caribbean tourism demand: issues in measurement and methodology. Atlantic Economic Journal, 19 (3), 32-40

CEDA (1997). various issues.

Fakhar, A. (2008). Factors affecting tourism, tourism potential and strategies for development as an industry in Pakistan. The Department of Business Administration, University of Gavle.

Ghartey, E.E. (2010). Tourism, economic growth and monetary policy in Jamaica. Department of Economics, the University of the West Indies, Kingston 7, Jamaica.

Gray, H.P. (1966). The demand for international travel by the United States and Canada. International Economic Review, 7(1), 83-92

Kaur, J. (1985). Himalayan pilgrimage and the new tourism. New Delhi: Himalayan Books.

Kim, H.J., Chen, M-H, \& Jang, S.S. (2006). Tourism expansion and economic development: the case of Taiwan. Tourism Management, 27(5), 925-933.

Krugman, P., and Helpman, E. (1985). Market structure and foreign trade. Cambridge, Massachusetts: The MIT Press.

Malik, S., Chaudhry, I. S., Sheikh, M.R., \& Farooqi, F.S. (2010). Tourism, economic growth and current account deficit in Pakistan: evidence from co-integration and causal analysis. European Journal of Economics, Finance and Administrative Science, 22, 21-31.

Ministry of Finance (MoF) (2018/19). Economic survey. Ministry of Finance, Kathmandu, Nepal.

O'Hagan, J.W., \& Harrison, M.J. (1984). Market Shares of US tourist expenditure in Europe: an econometric analysis. Applied Economics, 16, 919-931. 
Pant, P. R. (2014). Business environment in Nepal, Kathmandu: Buddha Academic Publishers and Distributors. Poudel, P.C. (1996). Tourist resources and environmental appraisal in Pokhara region, Nepal: A geographical analysis. The Department of Geography, Banaras Hindu University, India.

Pradhan, K.M. (2013). Significance of cultural tourism in Nepal. The Nepalese Management Review, 16(1), 1322.

Upadhyay, R. (2006). Tourism and economic development in Nepal: some highlights. Hotel Association of Nepal $(H A N)$, Kathmandu. 